\title{
Effect of incremental levels of apple pomace and multi enzyme on performance, immune response, gut development and blood biochemical parameters of broiler chickens
}

\author{
Amir Hosein Aghili ${ }^{1} \cdot$ Majid Toghyani ${ }^{1}$ (D) . Sayed Ali Tabeidian ${ }^{1}$
}

Received: 2 June 2019 / Accepted: 9 October 2019 / Published online: 14 November 2019

(c) The Author(s) 2019

\begin{abstract}
Purpose During the apple processing procedures, a large amount of apple pomace is generated which is contains peel, core, seed, calyx, stem, and soft issue. The polyphenolic compounds in apple pomace are strong antioxidants that are able to counterbalance the free radicals; also, it is a rich source of many nutrients such as carbohydrates, minerals, fiber except protein. The experiment was conducted to investigate the effect of different levels of dried apple pomace in broilers diet. Methods The incremental levels of dried apple pomace (4, 8, 12, 16 and 20\%) with and without enzyme were used in broilers diet ( 8 dietary treatments). The growth performance, immune response, gut development, antioxidant capacity (TAC) and blood biochemical parameters were evaluated.

Results The lowest daily weight gain, body weight and poorest feed conversion ratio was obtained by $\mathrm{F}$ treatment $(P<0.05)$, enzyme inclusion along with dried apple pomace had positive effect on growth performance. The antibody titter against Newcastle, Influenza and SRBC was increased by $\mathrm{C}, \mathrm{H}, \mathrm{G}$ and $\mathrm{H}$ treatments, respectively $(P<0.05)$. Antibody titer against NDV, IDV, and SRBC by $4,8,12$ and TAC by 12,16 and $20 \%$ of dried apple pomace significantly increased. The villous height by $4,8,12$ and crypt depth by 12,16 and $20 \%$ dried apple pomace significantly and insignificantly decreased, respectively. Conclusion The results suggested that the incremental levels of dried apple pomace deteriorate growth performance, modified antibody titer production, total antioxidant capacity and blood parameters of broilers.
\end{abstract}

Keywords Broiler $\cdot$ Dried apple pomace $\cdot$ Performance $\cdot$ Immunity $\cdot$ Blood parameter

\section{Abbreviations \\ DAP Dried apple pomace \\ SRBC Sheep red blood cell}

\section{Introduction}

Apples are well known and widespread fruits of the genus malus (about 25 species) belonging to the family Rosacea. Apple pomace is the main solid waste generated in apple juice making factories and contains $>80 \%$ moisture (Gullion et al. 2008). Apple pomace consists of apple peel, seeds, core, stems and pulp, and represents about $25-35 \%$ of the

Majid Toghyani

toghiani@ hotmail.com

1 Department of Animal Science, Islamic Azad University, Isfahan (Khorasgan) Branch, University Blvd, Arqavanieh, Jey Street, P.O. Box: 81595-158, Isfahan, Iran weight of the fresh apple processed (García Dineiro et al. 2009). Generally, the apple processing industry generates 25-30\% apple pomace and 5-10\% sludge.

Apple pulp is a rich source of pectin (10-15\%) and good source of carbohydrates, polyphenols and dietary fiber and has antioxidant property (Fanimo et al. 2003; Sudha et al. 2007), which is due to some phytochemicals such as total flavonoids $(0.45-1.19 \mathrm{mg} / \mathrm{g})$ phenolics $(4.22-8.67 \mathrm{mg} / \mathrm{g})$, and total flavan-3-ols (2.27-9.51 mg/g) (Cetkovic et al. 2007). Base on the findings of Ganai et al. (2006), apple pomace contains $19.34-20.66 \%$ crude fiber, $7.31-8.53 \%$ crude protein, 2.6-3.33\% ether extract, 46.4-49\% neutral detergent fiber and $3.85-4.7 \%$ total ash.

Apple pomace is presently used to feed animal but several factors such as low digestibility due to high lignin/cellulose ratio, low protein and mineral contents adversely affect the its value as an animal feed (Correia et al. 2007). Dried apple pomace can be potentially used as a supplement in poultry feed. 
The observation of Zafar et al. (2005) indicate that dry apple pomace can be used safely as an energy source in broiler rations replacing maize by $10 \%(\mathrm{w} / \mathrm{w})$ without any side-effects on broiler production. Inclusion of $15 \%$ apple pulp with $10 \%$ sugar beet molasses did not have any adverse effects on broilers performance (Ahmad 2004). Kilinc and Ayhan (2002) reported that dried apple pomace can be used up to $15 \%$ in quail diets. Ayhan et al. (2009) suggested that dried apple pomace can be used as a feed ingredient in broiler diets up to 5\%. Kang et al. (2009) suggested the possibility that fermented of apple pomace could be used as an alternative to antibiotic growth promoters to improve the performance and meat quality of broiler chickens. Akhlaghi et al. (2014) have demonstrated that herbal antioxidants such as dried tomato pomace, sage extract, dried ginger rhizome and dried apple pomace improve semen quality in poultry.

Beneficial effects of fruit pomaces on blood parameters were noted in piglets fed diets supplemented with apple pomace (Sehm et al. 2011). In rats using apple pulp for 4 weeks significantly reduced their blood triglyceride and cholesterol level (Khayat Nouri and Kargari Rezapour 2011). Because of low nutrients digestibility of apple pomace, some researchers supplemented multi enzyme with apple pomace in poultry diets. Matoo et al. (2001) have reported better performance of broilers fed on apple pomace diets supplemented with a commercial enzyme preparation (alpha-amylase, hemicellulose, protease and beta-glucanase) compared with those that were not supplemented. Yildiz et al. (1998) reported that egg production and feed efficiency were influenced positively while live weight, egg breaking strength and egg shell thickness were not influenced by addition of $5 \%$ dried apple pomace with multi enzyme (hemi-cellulase, pentosanase, beta-glucanase, pectinase, protease, amylase) to the layer rations.

However, to date, no information has been published about the effects of incremental levels of apple pomace in poultry diets. Therefore, this study was performed to determine the effect of incremental levels of apple pomace with and without multi enzyme complex on performance, immune responses, gut development, total antioxidant capacity and some blood serum biochemical parameters of broiler chickens.

\section{Materials and methods}

\section{Apple pomace preparation and analysis}

Fresh apple pomace was provided from a local producer, dried in the oven $\left(55^{\circ} \mathrm{C}\right)$, ground and was added into broilers diet. Chemical composition of dried apple pomace was determined according to (AOAC 1994) which contained $900 \mathrm{~g} / \mathrm{kg}$ dry matter, $370 \mathrm{~g} / \mathrm{kg}$ crude protein, $29 \mathrm{~g} / \mathrm{kg}$ ether extract, $92 \mathrm{~g} / \mathrm{kg}$ crude fiber, $3 \mathrm{~g} / \mathrm{kg}$ calcium and $1 \mathrm{~g} / \mathrm{kg}$ phosphorous. The chemically analysed of apple pomace is presented in Table 1. The metabolizable energy, lysine, methionine + cysteine, threonine content of DAP was considered respectively, $2700 \mathrm{kcal} / \mathrm{kg}, 4.3,1$ and $1.5 \mathrm{~g} / \mathrm{kg}$ (Toghyani and Emadinia 2016).

\section{Birds and dietary treatments}

Four-hundred-eighty day-old mixed sex broiler chicks (Ross 308) were purchased from a local hatchery, weighted individually on arrival time, and randomly allocated to 8 treatments and 5 replicate pens of 12 chicks each in completely randomized design. Dietary treatments included: A: control (0\% DAP); C: 4,8 and 12\% DAP; E: 8,12 and $16 \%$ DAP and G: 12,16 and $20 \%$ DAP, in starter, grower and finisher diets, respectively. Other dietary treatments supplemented with multi enzyme and contained $\mathrm{B}$ $(\mathrm{A}+$ enzyme $), \mathrm{D}(\mathrm{C}+$ enzyme $), \mathrm{F}(\mathrm{E}+$ enzyme $)$ and $\mathrm{H}$ $(\mathrm{G}+$ enzyme) (Table 2$)$.

Diets were formulated to be isocaloric and isonitrogenous in starter (1-14 days), grower (15-28 days) and finisher (29-42 days) periods and to meet bird requirements according to the recommendation of Ross broiler manual (2014) (Tables 3, 4, 5). The commercial multi enzyme as a rate of $0.5 \mathrm{~g} / \mathrm{kg}$ of diet were used and contain a pectinase, proteases, endo-1,4-beta-mannanase and beta-mannosidase and beta-D-glucanase (Rovabio ${ }^{\circledR}$ Excel, Adisseo Co, France).

Chicks were raised in floor pens $\left(10 \mathrm{birds} / \mathrm{m}^{2}\right)$ for 6 weeks. Feed and water were provided ad libitum throughout the experiment. The lighting program consisted of a period of $23 \mathrm{~h}$ light and $1 \mathrm{~h}$ of darkness. The ambient temperature was gradually decreased from 33 to $24{ }^{\circ} \mathrm{C}$ on day 21 and then was kept constant. All experimental procedures were evaluated and approved by the Institutional Animal Care and Ethics Committee of the Islamic Azad University of Isfahan.

Table 1 Chemical analysis of dried apple pomace

\begin{tabular}{lc}
\hline Nutrient & Percentage \\
\hline Moisture & 6.40 \\
Fiber & 9.00 \\
Ether extract & 26.70 \\
Ash & 5.34 \\
$\mathrm{Ca}$ & 3.72 \\
$\mathrm{P}$ & 0.30 \\
Na & 0.18 \\
Nitrogen free extract & 48.80 \\
\hline
\end{tabular}


Table 2 Dietary treatments in different rearing periods of broiler chicks

\begin{tabular}{lllll}
\hline \multicolumn{5}{l}{ \% Dried apple pomace (DAP) in diets } \\
\hline Treatments & $\begin{array}{l}\text { Starter } \\
(1-14 \text { days })\end{array}$ & $\begin{array}{l}\text { Grower } \\
(14- \\
28 \text { days })\end{array}$ & $\begin{array}{l}\text { Finisher } \\
(28- \\
42 \text { days })\end{array}$ & Multi enzyme \\
\hline A & 0 & 0 & 0 & - \\
B & 0 & 0 & 0 & + \\
C & 4 & 8 & 12 & - \\
D & 4 & 8 & 12 & + \\
E & 8 & 12 & 16 & - \\
F & 8 & 12 & 16 & + \\
G & 12 & 16 & 20 & - \\
H & 12 & 16 & 20 & + \\
\hline
\end{tabular}

A: control (0\% DAP); C: 4,8 and $12 \%$ DAP; E: 8,12 and $16 \%$ DAP and G: 12,16 and 20\% DAP, in starter, grower and finisher diets, respectively. Other dietary treatments supplemented with multi enzyme and contained B (A+enzyme), D (C+enzyme), $\mathrm{F}$ (E+enzyme) and $\mathrm{H}(\mathrm{G}+$ enzyme $)$

\section{Growth performance parameters}

Body weight and feed intake of broilers were recorded at $1,14,28$ and 42 days of age using pens as the experimental units. Feed conversion ratio (FCR) (feed intake/weight gain) was also calculated. Mortality was recorded as it occurred.

\section{Carcass components and digestive organs}

On day 42 of experiment, two birds with body weight close to the mean body weight (BW) of their pen were selected, individually weighed and slaughtered. Carcass yield, abdominal fat, liver and heart were collected, weighed and expressed as a percentage of live BW.

Weight of digestive organs including pancreas, proventriculus, gizzard, small intestine and cecum were measured on day 42 and expressed as a percentage of live BW. The length of intestinal segments consisted of duodenum, jejunum, ileum and cecum were also measured and recorded.

\section{Immune system parameters}

At 29 days of age, Newcastle and Influenza antigens were injected to chickens with dual vaccine of Newcastle-influenza. Two chickens per pen were selected randomly for the brachial vein injection with a $1.0 \mathrm{ml}$ of sheep red blood cells (SRBC) suspension diluted with phosphate buffer saline (pbs) on day 22. Six days later, the same wing-banded birds were bled to determine antibody titer against SRBC and also against influenza and Newcastle.

Subsequently antibody titer against SRBC was measured by haemagglutination assay method and also antibody titer against Influenza and Newcastle was separately measured by haemagglutination inhibition method. Haemagglutination inhibition antibodies were then converted to $\log _{2}$. Antibody titers against SRBC were measured by the microtiter procedure described by Wegmann and Smithies (1966). At the end of the experiment, two birds per pen were slaughtered, spleen and bursa of Fabricius was collected and weighed to determination of lymphoid organ weight.

\section{Small intestinal morphology}

On day 28 of age, two birds of each pen were slaughtered and intestinal samples were taken immediately from the jejunum; midway between the point of entry of the bile ducts and Meckel's diverticulum, ileum; $10 \mathrm{~cm}$ proximal to the ileo-cecal junction were taken to evaluate the villous height, crypt depth and villous height: crypt depth ratio (V/C). Segments which were $1.5 \mathrm{~cm}$ in length were flushed with saline and fixed in $100 \mathrm{~g} \mathrm{~L}^{-1}$ buffered formalin $(\mathrm{pH}$

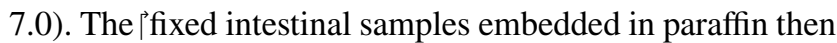
sectioned $(5 \mu \mathrm{m})$ and 'stained with hematoxylin-eosin and examined by light microscope (Nikon, Japan). A total of 10 intact, well-oriented villous-crypt units were selected for each intestinal cross sections (3 cross sections/sample and 30 cross sections/treatment). Villous height $(\mu \mathrm{m})$ was measured from the tip of the villous to the villous crypt junction and crypt depth was measured from the base upward to the region fof transition between the crypt and $\mathrm{V} / \mathrm{C}$ was then calculated (Carrijo et al. 2005).

\section{Biochemical blood parameters}

After $12 \mathrm{~h}$ fasting, blood samples from 2 birds per pen were collected in non-heparinised and heparinized tube at 42 days by puncturing the brachial vein, the blood samples were centrifuged $(2000 \times g$ for $10 \mathrm{~min})$ and serum or plasma stored at $-20{ }^{\circ} \mathrm{C}$. Individual serum samples were analyzed for triglyceride, cholesterol, HDL and LDL cholesterol using the kit package (Pars Azmoon Co., Ltd., Tehran, Iran).

For determination of total antioxidant capacity (TAC), individual plasma samples were analyzed according to the method of Benize and Strain (1996). Briefly, a working solution of ferric reducing antioxidant power (FRAP) was provided by mixing 10 volumes of buffer acetate $(300 \mu \mathrm{mol} / \mathrm{L}$, $\mathrm{pH}$ 3.6) with 1 volume TPTZ solution in HCL ( $40 \mathrm{Mm} / \mathrm{L})$. After that, $1 \mathrm{~mL}$ solution of $\mathrm{FeCl}_{3}(20 \mathrm{mM} / \mathrm{L})$ was added and mixed. For measurement, $1.5 \mathrm{~mL}$ of FRAP working solution was put in the cuvette and incubated for $10 \mathrm{~min}$ at room temperature, then the optical density of the blank was measured spectrophotometrically at $532 \mathrm{~nm}$. For test samples, $50 \mu \mathrm{L}$ of plasma replaced by the working solution, and change in absorbance was measured. 
Table 3 Ingredients $(\mathrm{g} / \mathrm{kg})$ and calculated analysis of dietary treatments in starter period (1-14 days)

\begin{tabular}{|c|c|c|c|c|c|c|c|c|}
\hline \multicolumn{9}{|l|}{ Dietary treatments ${ }^{\mathrm{a}}$} \\
\hline Feed ingredients $(\mathrm{g} / \mathrm{kg})$ & A & B & $\mathrm{C}$ & $\mathrm{D}$ & $\mathrm{E}$ & $\mathrm{F}$ & G & $\mathrm{H}$ \\
\hline Corn $(7.25 \%)$ & 543.6 & 543.6 & 498.9 & 498.9 & 455.3 & 455.3 & 411.9 & 411.9 \\
\hline Soybean meal (45\%) & 400 & 400 & 400 & 400 & 400 & 400 & 400 & 400 \\
\hline Dried apple pomace & 0 & 0 & 40 & 40 & 80 & 80 & 120 & 120 \\
\hline Soybean oil & 18 & 18 & 22 & 22 & 26 & 26 & 29.6 & 29.6 \\
\hline Dicalcium phosphate & 18.1 & 18.1 & 18 & 18 & 17.7 & 17.7 & 17.5 & 17.5 \\
\hline Calcium carbonate & 10 & 10 & 9.7 & 9.7 & 9.5 & 9.5 & 9.4 & 9.4 \\
\hline $\mathrm{NaCl}$ & 3 & 3 & 3 & 3 & 3 & 3 & 3 & 3 \\
\hline Vitamin premix ${ }^{b}$ & 1.25 & 1.25 & 1.25 & 1.25 & 1.25 & 1.25 & 1.25 & 1.25 \\
\hline Mineral premix ${ }^{c}$ & 1.25 & 1.25 & 1.25 & 1.25 & 1.25 & 1.25 & 1.25 & 1.25 \\
\hline L-Lysine. $\mathrm{HCl}$ & 3 & 3 & 1.9 & 1.9 & 1.9 & 1.9 & 1.9 & 1.9 \\
\hline DL-Methionine & 1.3 & 1.3 & 3.4 & 3.4 & 3.5 & 3.5 & 3.6 & 3.6 \\
\hline L-Threonine & 0.5 & 0.5 & 0.6 & 0.6 & 0.6 & 0.6 & 0.6 & 0.6 \\
\hline \multicolumn{9}{|l|}{ Calculated composition } \\
\hline Metabolizable energy (kcal/kg) & 2800 & 2800 & 2800 & 2800 & 2800 & 2800 & 2800 & 2800 \\
\hline Crude protein $(\mathrm{g} / \mathrm{kg})$ & 220 & 220 & 220 & 220 & 220 & 220 & 220 & 220 \\
\hline Calcium (g/kg) & 9.2 & 9.2 & 9.2 & 9.2 & 9.2 & 9.2 & 9.2 & 9.2 \\
\hline Available phosphorus (g/kg) & 4.5 & 4.5 & 4.5 & 4.5 & 4.5 & 4.5 & 4.5 & 4.5 \\
\hline Lysine (g/kg) & 13.8 & 13.8 & 13.8 & 13.8 & 13.8 & 13.8 & 13.8 & 13.8 \\
\hline Methionine + cysteine $(\mathrm{g} / \mathrm{kg})$ & 10.3 & 10.3 & 10.3 & 10.3 & 10.3 & 10.3 & 10.3 & 10.3 \\
\hline Threonine $(\mathrm{g} / \mathrm{kg})$ & 9.3 & 9.3 & 9.3 & 9.3 & 9.3 & 9.3 & 9.3 & 9.3 \\
\hline
\end{tabular}

A: control (0\% DAP); C: 4, 8 and 12\% DAP; E: 8, 12 and 16\% DAP and G: 12, 16 and 20\% DAP, in starter, grower and finisher diets, respectively. Other dietary treatments supplemented with multienzyme and contained B (A+enzyme), D (C+enzyme), F (E+enzyme) and H ( $\mathrm{G}+$ enzyme)

$D A P$ dried apple pomace

${ }^{\mathrm{b}}$ Vitamin premix per kg of diet: vitamin A (retinol), $2.7 \mathrm{mg}$; vitamin D3 (Cholecalciferol), $0.05 \mathrm{mg}$; vitamin E (tocopheryl acetate), $30 \mathrm{mg}$; vitamin $\mathrm{k} 3,2 \mathrm{mg}$; thiamine $1.8 \mathrm{mg}$; riboflavin, $6.6 \mathrm{mg}$; pantothenic acid, $10 \mathrm{mg}$; pyridoxine, $3 \mathrm{mg}$; cyanocobalamin, $0.015 \mathrm{mg}$; niacin, $30 \mathrm{mg}$; biotin, $0.1 \mathrm{mg}$; folic acid, $1 \mathrm{mg}$; choline chloride, $250 \mathrm{mg}$; antioxidant $100 \mathrm{mg}$

${ }^{\mathrm{c}}$ Mineral premix per $\mathrm{kg}$ of diet: $\mathrm{Fe}\left(\mathrm{FeSO}_{4} \cdot 7 \mathrm{H}_{2} \mathrm{O}, 20.09 \% \mathrm{Fe}\right), 50 \mathrm{mg} ; \mathrm{Mn}\left(\mathrm{MnSO}_{4} \cdot \mathrm{H}_{2} \mathrm{O}, 32.49 \% \mathrm{Mn}\right)$, $100 \mathrm{mg}$; $\mathrm{Zn}(\mathrm{ZnO}, 80.35 \% \mathrm{Zn}), 100 \mathrm{mg} ; \mathrm{Cu}\left(\mathrm{CuSO}_{4} \cdot 5 \mathrm{H}_{2} \mathrm{O}\right), 10 \mathrm{mg}$; I (KI, 58\% I), $1 \mathrm{mg} ; \mathrm{Se}\left(\mathrm{NaSeO}_{3}\right.$, $45.56 \% \mathrm{Se}), 0.2 \mathrm{mg}$

\section{Statistical analysis}

The data were subjected to analysis of variance procedures appropriate for a completely randomized design in a factorial arrangement $(2 \times 4)$ using the GLM procedures of SAS (1997). Means were compared for significant $(P \leq 0.05)$ differences by using the LSMEANS. Statements of significance are based on $P \leq 0.05$ unless otherwise noted.

\section{Results and discussion}

\section{Performance parameters}

Table 6 shows the interaction and main effects of dried apple pomace (DAP) and enzyme supplementation on performance parameters of broilers at different rearing phases. Daily feed intake (DFI) in overall rearing phase was not affected by interaction effect of DAP and enzyme supplementation $(P>0.05)$. DFI in starter phase (1-14 days) showed significant difference between $\mathrm{G}$ and $\mathrm{B}$ treatments; also, lower and higher DFI obtained in $\mathrm{G}$ and $\mathrm{B}$ treatments, respectively $(P<0.05)$.

In grower phase, significant difference was observed between $\mathrm{C}$ and $\mathrm{G}$ treatments $(P<0.05)$, higher and lower DFI was observed in $\mathrm{C}$ and $\mathrm{G}$ treatments, respectively $(P<0.05)$. In finisher phase, DFI in B treatment significantly decreased as compared with $\mathrm{H}$ treatment and control group $(P<0.05)$.

The main effect of enzyme had no significant effect on DFI at different rearing phases $(P>0.05)$. The inclusion of 12,16 and 20\% DAP in starter phase significantly decreased DFI $(P<0.05)$, highest DFI was gained in control group $(P<0.05)$. In grower phase, the highest DFI was belong to 4,8 and $12 \%$ DAP $(P<0.05)$. In finisher 
Table 4 Ingredients $(\mathrm{g} / \mathrm{kg})$ and calculated analysis of dietary treatments in grower period (15-28 days)

\begin{tabular}{|c|c|c|c|c|c|c|c|c|}
\hline \multicolumn{9}{|l|}{ Dietary treatments ${ }^{\mathrm{a}}$} \\
\hline Feed ingredients $(\mathrm{g} / \mathrm{kg})$ & A & B & $\mathrm{C}$ & $\mathrm{D}$ & $\mathrm{E}$ & $\mathrm{F}$ & G & $\mathrm{H}$ \\
\hline Corn $(7.25 \%)$ & 582.6 & 582.6 & 496.7 & 496.7 & 453 & 453 & 411.1 & 411.1 \\
\hline Soybean meal (CP 45\%) & 361 & 361 & 359 & 359 & 359 & 359 & 357 & 357 \\
\hline Apple pomace & 0 & 0 & 80 & 80 & 120 & 120 & 160 & 160 \\
\hline Soybean oil & 21 & 21 & 29 & 29 & 33 & 33 & 37 & 37 \\
\hline Dicalcium phosphate & 16 & 16 & 16 & 16 & 15.8 & 15.8 & 15.8 & 15.8 \\
\hline Calcium carbonate & 9.1 & 9.1 & 8.6 & 8.6 & 8.3 & 8.3 & 8 & 8 \\
\hline $\mathrm{NaCl}$ & 3 & 3 & 3 & 3 & 3 & 3 & 3 & 3 \\
\hline Vitamin premix ${ }^{b}$ & 1.5 & 1.5 & 1.5 & 1.5 & 1.5 & 1.5 & 1.5 & 1.5 \\
\hline Mineral premix ${ }^{c}$ & 1.5 & 1.5 & 1.5 & 1.5 & 1.5 & 1.5 & 1.5 & 1.5 \\
\hline L-Lysine. $\mathrm{HCl}$ & 1.3 & 1.3 & 1.3 & 1.3 & 1.2 & 1.2 & 1.2 & 1.2 \\
\hline DL-Methionine & 2.8 & 2.8 & 3 & 3 & 3.2 & 3.2 & 3.3 & 3.3 \\
\hline L-Threonine & 0.2 & 0.2 & 0.4 & 0.4 & 0.5 & 0.5 & 0.6 & 0.6 \\
\hline \multicolumn{9}{|l|}{ Calculated composition } \\
\hline Metabolizable energy (kcal/kg) & 2950 & 2950 & 2950 & 2950 & 2950 & 2950 & 2950 & 2950 \\
\hline Crude protein $(\mathrm{g} / \mathrm{kg})$ & 204.6 & 204.6 & 204.6 & 204.6 & 204.6 & 204.6 & 204.6 & 204.6 \\
\hline Calcium (g/kg) & 8.3 & 8.3 & 8.3 & 8.3 & 8.3 & 8.3 & 8.3 & 8.3 \\
\hline Available phosphorus (g/kg) & 4.1 & 4.1 & 4.1 & 4.1 & 4.1 & 4.1 & 4.1 & 4.1 \\
\hline Lysine (g/kg) & 12.3 & 12.3 & 12.3 & 12.3 & 12.3 & 12.3 & 12.3 & 12.3 \\
\hline Methionine + cysteine $(\mathrm{g} / \mathrm{kg})$ & 9.4 & 9.4 & 9.4 & 9.4 & 9.4 & 9.4 & 9.4 & 9.4 \\
\hline Threonine $(\mathrm{g} / \mathrm{kg})$ & 9.3 & 9.3 & 9.3 & 9.3 & 9.3 & 9.3 & 9.3 & 9.3 \\
\hline
\end{tabular}

A: control (0\% DAP); C: 4, 8 and 12\% DAP; E: 8, 12 and 16\% DAP and G: 12, 16 and 20\% DAP, in starter, grower and finisher diets, respectively. Other dietary treatments supplemented with multienzyme and contained B (A+enzyme), D (C+enzyme), F (E+enzyme) and H ( $\mathrm{G}+$ enzyme)

$D A P$ dried apple pomace

${ }^{\mathrm{b}}$ Vitamin premix per $\mathrm{kg}$ of diet: vitamin A (retinol), $2.7 \mathrm{mg}$; vitamin D3 (cholecalciferol), $0.05 \mathrm{mg}$; vitamin E (tocopheryl acetate), $30 \mathrm{mg}$; vitamin $\mathrm{k} 3,2 \mathrm{mg}$; thiamine $1.8 \mathrm{mg}$; riboflavin, $6.6 \mathrm{mg}$; pantothenic acid, $10 \mathrm{mg}$; pyridoxine, $3 \mathrm{mg}$; cyanocobalamin, $0.015 \mathrm{mg}$; niacin, $30 \mathrm{mg}$; biotin, $0.1 \mathrm{mg}$; folic acid, $1 \mathrm{mg}$; choline chloride, $250 \mathrm{mg}$; Antioxidant $100 \mathrm{mg}$

${ }^{\mathrm{c}}$ Mineral premix per $\mathrm{kg}$ of diet: $\mathrm{Fe}\left(\mathrm{FeSO}_{4} \cdot 7 \mathrm{H}_{2} \mathrm{O}, 20.09 \% \mathrm{Fe}\right), 50 \mathrm{mg} ; \mathrm{Mn}\left(\mathrm{MnSO}_{4} \cdot \mathrm{H}_{2} \mathrm{O}, 32.49 \% \mathrm{Mn}\right)$, $100 \mathrm{mg}$; $\mathrm{Zn}(\mathrm{ZnO}, 80.35 \% \mathrm{Zn}), 100 \mathrm{mg} ; \mathrm{Cu}\left(\mathrm{CuSO}_{4} \cdot 5 \mathrm{H}_{2} \mathrm{O}\right), 10 \mathrm{mg}$; I (KI, 58\% I), $1 \mathrm{mg} ; \mathrm{Se}\left(\mathrm{NaSeO}_{3}\right.$, $45.56 \% \mathrm{Se}), 0.2 \mathrm{mg}$ and overall rearing phase, DFI did not affect with different levels of DAP in broiler diet $(P>0.05)$.

In starter phase the DWG of broilers fed on $\mathrm{G}$ treatment significantly decreased $(P<0.05)$. In grower phase, DWG decreased and increased by $\mathrm{G}$ and $\mathrm{C}$ treatments, respectively $(P<0.05)$. In finisher and overall rearing phases DWG decreased by $\mathrm{F}$ treatment, and highest DWG was observed in control group $(P<0.05)$.

The main effect of enzyme supplementation had no significant effect on DWG of broilers; although, enzyme supplementation numerically increased it in different rearing phases $(P>0.05)$. The main effect of DAP showed that DWG in control group increased in starter, grower, finisher and overall phase $(P<0.05)$, and significantly was high in finisher phase $(P>0.05)$.

In starter phase FCR of broilers was not affected by interaction effect of DAP and enzyme supplementation, and the special trend was not observed $(P>0.05)$. While, in grower phase FCR of broilers fed on $\mathrm{H}$ treatment significantly increased $(P<0.05)$, and control group had the lowest FCR $(P<0.05)$. In finisher and overall rearing phases, FCR of broilers decreased and increased by $\mathrm{B}$ and $\mathrm{F}$ treatments, respectively $(P<0.05)$.

Main effect of enzyme supplementation on FCR was not significant $(P<0.05)$. In starter phase the specific trend in FCR of broilers was not observed between main effect of DAP $(P>0.05)$. In grower, finisher and overall rearing phases, lowest FCR was obtained in control group $(P<0.05)$ and highest FCR was obtained in 12, 16 and 20 DAP inclusion $(P<0.05)$.

The obtained results showed that, BW of broilers at 14 and 42 days of age in control group as compared with $G$ treatment was significantly increased $(P<0.05)$; however, at 28 days of age broilers received $\mathrm{G}$ and $\mathrm{B}$ treatments had lowest and highest BW, respectively $(P<0.05)$. The BW of broilers at different rearing phases was not affected by main 
Table 5 Ingredients $(\mathrm{g} / \mathrm{kg})$ and calculated analysis of dietary treatments in finisher period (29-42 days)

\begin{tabular}{lllllllll}
\hline $\begin{array}{l}\text { Feed ingredients }(\mathrm{g} / \mathrm{kg}) \\
\text { Dietary treatments }\end{array}$ & $\mathrm{A}$ & $\mathrm{B}$ & $\mathrm{C}$ & $\mathrm{D}$ & $\mathrm{E}$ & $\mathrm{F}$ & $\mathrm{G}$ & $\mathrm{H}$ \\
\hline Corn $(7.25 \%)$ & & & & & & & & \\
Soybean meal (CP 45\%) & 642.3 & 642.3 & 514.4 & 514.4 & 471.7 & 471.7 & 428.8 & 428.8 \\
Apple pomace & 306 & 306 & 302 & 302 & 301 & 301 & 300 & 300 \\
Soybean oil & 0 & 0 & 120 & 120 & 160 & 160 & 200 & 200 \\
Dicalcium phosphate & 20 & 20 & 32.3 & 32.3 & 36 & 36 & 40 & 40 \\
Calcium carbonate & 13.8 & 13.8 & 13.7 & 13.7 & 13.7 & 13.7 & 13.7 & 13.7 \\
NaCl & 8.4 & 8.4 & 7.5 & 7.5 & 7.3 & 7.3 & 7 & 7 \\
Vitamin premix & 3 & 3 & 3 & 3 & 3 & 3 & 3 & 3 \\
Mineral premix & 1.5 & 1.5 & 1.5 & 1.5 & 1.5 & 1.5 & 1.5 & 1.5 \\
L-Lysine. HCl & 1.5 & 1.5 & 1.5 & 1.5 & 1.5 & 1.5 & 1.5 & 1.5 \\
DL-Methionine & 1.2 & 1.2 & 1.1 & 1.1 & 1.1 & 1.1 & 1 & 1 \\
L-Threonine & 2.3 & 2.3 & 2.7 & 2.7 & 2.8 & 2.8 & 3 & 3 \\
Calculated composition & 0 & 0 & 0.3 & 0.3 & 0.4 & 0.4 & 0.5 & 0.5 \\
Metabolizable energy (kcal/kg) & 3020 & 3020 & 3020 & 3020 & 3020 & 3020 & 3020 & 3020 \\
Crude protein (g/kg) & 184 & 184 & 184 & 184 & 184 & 184 & 184 & 184 \\
Calcium (g/kg) & 7.4 & 7.4 & 7.4 & 7.4 & 7.4 & 7.4 & 7.4 & 7.4 \\
Available phosphorus $(\mathrm{g} / \mathrm{kg})$ & 3.7 & 3.7 & 3.7 & 3.7 & 3.7 & 3.7 & 3.7 & 3.7 \\
Lysine (g/kg) & 10.8 & 10.8 & 10.8 & 10.8 & 10.8 & 10.8 & 10.8 & 10.8 \\
Methionine + cysteine $(\mathrm{g} / \mathrm{kg})$ & 8.5 & 8.5 & 8.5 & 8.5 & 8.5 & 8.5 & 8.5 & 8.5 \\
Threonine $(\mathrm{g} / \mathrm{kg})$ & 7.4 & 7.4 & 7.4 & 7.4 & 7.4 & 7.4 & 7.4 & 7.4 \\
\hline
\end{tabular}

A: control (0\% DAP); C: 4, 8 and 12\% DAP; E: 8, 12 and 16\% DAP and G: 12, 16 and 20\% DAP, in starter, grower and finisher diets, respectively. Other dietary treatments supplemented with multienzyme and contained B (A+enzyme), D (C+enzyme), F (E+enzyme) and $\mathrm{H}(\mathrm{G}+$ enzyme $)$

$D A P$ dried apple pomace

${ }^{\mathrm{b}}$ Vitamin premix per kg of diet: vitamin A (retinol), $2.7 \mathrm{mg}$; vitamin D3 (cholecalciferol), $0.05 \mathrm{mg}$; vitamin E (tocopheryl acetate), $30 \mathrm{mg}$; vitamin $\mathrm{k} 3,2 \mathrm{mg}$; thiamine $1.8 \mathrm{mg}$; riboflavin, $6.6 \mathrm{mg}$; pantothenic acid, $10 \mathrm{mg}$; pyridoxine, $3 \mathrm{mg}$; cyanocobalamin, $0.015 \mathrm{mg}$; niacin, $30 \mathrm{mg}$; biotin, $0.1 \mathrm{mg}$; folic acid, $1 \mathrm{mg}$; choline chloride, $250 \mathrm{mg}$; Antioxidant $100 \mathrm{mg}$

${ }^{\mathrm{c}}$ Mineral premix per $\mathrm{kg}$ of diet: $\mathrm{Fe}\left(\mathrm{FeSO}_{4} \cdot 7 \mathrm{H}_{2} \mathrm{O}, 20.09 \% \mathrm{Fe}\right), 50 \mathrm{mg} ; \mathrm{Mn}\left(\mathrm{MnSO}_{4} \cdot \mathrm{H}_{2} \mathrm{O}, 32.49 \% \mathrm{Mn}\right)$, $100 \mathrm{mg}$; $\mathrm{Zn}(\mathrm{ZnO}, 80.35 \% \mathrm{Zn}), 100 \mathrm{mg} ; \mathrm{Cu}\left(\mathrm{CuSO}_{4} \cdot 5 \mathrm{H}_{2} \mathrm{O}\right), 10 \mathrm{mg}$; $(\mathrm{KI}, 58 \% \mathrm{I}), 1 \mathrm{mg} ; \mathrm{Se}\left(\mathrm{NaSeO}_{3}\right.$, $45.56 \% \mathrm{Se}), 0.2 \mathrm{mg}$ effect of enzyme inclusion $(P>0.05)$. The results related to main effect of DAP on BW of broilers showed that highest and lowest BW was belong to control group and 12, 16 and $20 \%$ DAP inclusion, respectively $(P<0.05)$.

As mentioned previously body weight of broilers in different rearing phases affected by DAP and interaction effect of DAP and enzyme supplementation in their diets $(P<0.05)$. Similar to obtained results, Heidarisafar et al. (2016) observed that $50 \mathrm{~g} / \mathrm{kg}$ apple peel waste caused to similar body weight to control group, and inclusion of $100 \mathrm{~g} / \mathrm{kg}$ apple peel waste decreased body weight of broilers at 42 days of age. Also, they observed that adding multi enzyme to broiler diet had no effect on body weight of broilers at 42 or 49 days of age, which is disagree with obtained results in recent study.

Feed intake reduction of broilers received 12, 16 and $20 \%$ DAP might be attributed to the high fiber content of these diets. Incorporation of fruit by-products with high fiber seemingly affects birds to modify their feed intake and preserve adequate energy consumption. The excessive use of fiber sources may also increase the viscosity of intestinal content and decreases bioavailability of nutrients (Heidarisafar et al. 2016).

As it is seen, enzyme supplementation non-significantly increased DFI, DWG of broilers in different rearing phases and BW at 28 and 42 days of age $(P>0.05)$. A considerable improvement in growth and FCR of poultries are signs of enzyme supplementation in their diet (Hesselman and Aman 1986; Campbell et al. 1986; Pettersson and Aman 1986; Choct et al. 1996), although, the mode of action of enzymes in broilers diet is not fully understood. It should be noted that the effects of enzymes are not equal, because they obtained from different sources, and the type, activity, optimum $\mathrm{pH}$, thermo stability and resistance against digestive tract hydrolysis are not same. 


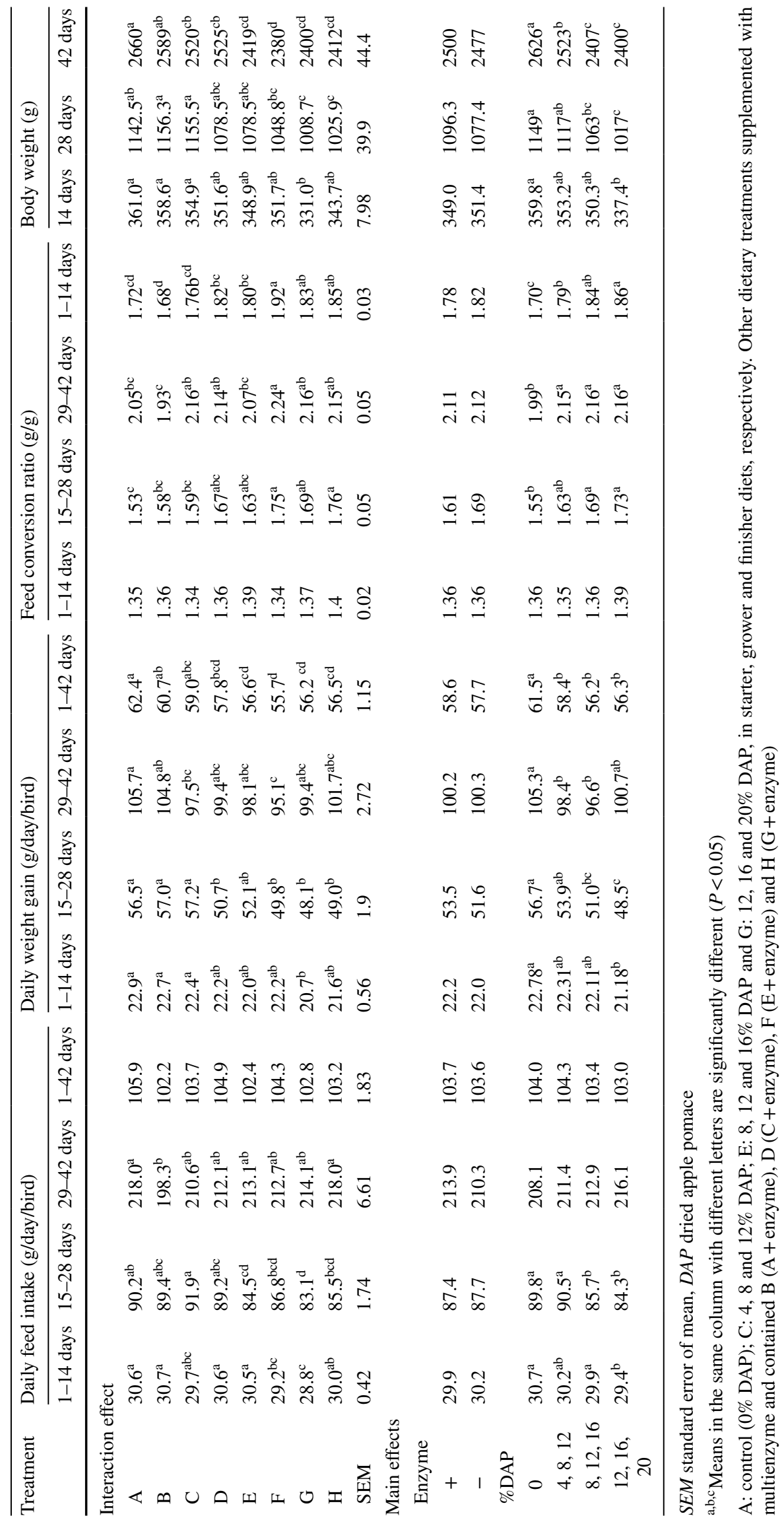


Bedford and Patridge (2011) reported that exogenous enzymes are able to hydrolyze NSP, pectin and crude fiber, so the nutrients are release and absorbed by intestinal villous.

\section{Carcass characteristics}

Table 7 demonstrate the interaction and main effects of DAP and enzyme supplementation in diet on carcass characteristics and internal organs of broilers. Among above mentioned parameters heart, liver, pancreas, bursa of fabricius, and spleen based on percentage of live body weight, and also length of duodenum, ileum and cecum of broilers were not affected by interaction of DAP and enzyme supplementation $(P>0.05)$.

Feeding broilers with B treatment cause to increase carcass yield and abdominal fat weight $(P<0.05)$, while in control group and $\mathrm{E}$ treatment lowest carcass yield and abdominal fat obtained $(P<0.05)$. The gizzard weight of broilers increased and decreased in $\mathrm{H}$ and $\mathrm{B}$ treatments, respectively $(P<0.05)$. Treatments A and B caused to proventriculus weight reduced $(P<0.05)$. Treatment $\mathrm{G}$ reduced duodenum weight of broilers $(P<0.05)$; although, $\mathrm{G}$ treatment caused to weights of jejunum and ileum has been increased $(P<0.05)$. Meanwhile A and B treatments decreased weight of jejunum and ileum $(P<0.05)$. Cecum length in $\mathrm{B}$ and $\mathrm{H}$ treatments had lowest and greatest weight, respectively $(P<0.05)$.

The data obtained related to main effects of enzyme supplementation showed that adding enzyme significantly increased carcass yield, weight of abdominal fat, proventriculus, jejunum and cecum $(P<0.05)$.

Main effects of DAP on carcass traits and internal organs showed that, weights of liver, proventriculus, duodenum, jejunum, ileum and length of duodenum, jejunum and ileum significantly enhanced $(P<0.05)$; also, gizzard weight and cecum length non-significantly increased in broilers fed on diets contain 12, 16 and 20\% DAP $(P>0.05)$. Carcass yield and abdominal fat decreased by 12,16 and $20 \%$ DAP in broiler diets $(P<0.05)$.

In the study of Heidarisafar et al. (2016), relative weights of internal organs were not affected by inclusion of apple peel waste in the diet, which is in agreement with obtained results except for weights of gizzard, pancreas, bursa of fabricius, spleen, and cecum length. The findings of Rizal et al. (2010) support the observation of recent study, they reported that inclusion of fruit juice waste mixture (carrot, apple, mango, avocado, orange, melon and tree tomato) in diet of broilers had no effect on pancreas and gizzard weights.

Nobakht (2013) used 1.5, 3 and $4.5 \%$ of dried lemon pulp in diet of broilers. Among carcass characteristics, the abdominal fat and gizzard weights of broilers significantly affected by inclusion of dried lemon pulp $(P<0.05)$. The present findings about abdominal fat are in agreement with findings of Rizal et al. (2010). They used dried juice waste up to $20 \%$ in broiler diets, the percentage of abdominal fat significantly decreased without significant effect on gizzard percent.

Our observation in gizzard weight was in agreed with reported results of Chaudry et al. (2004), who observed that the percentage of gizzard significantly increased, by inclusion of 5 and $10 \%$ citrus pulp in broiler diets. They implied that high crude fiber in the diet was the main factor that increased gizzard percent.

\section{Lymphoid organs and immune response}

The interaction and main effects of DAP and enzyme supplementation on immune response and lymphoid organs of broilers are listed in Table 8 . The spleen and bursa of fabricius weight of broilers were affected by experimental diets $(P>0.05)$. In general, antibody titer production against sheep red blood cell (SRBC), Newcastle and Influenza disease virus was lowest in control group $(P<0.05)$, and were not influenced by enzyme supplementation in broilers diet $(P>0.05)$. Broilers received $\mathrm{C}$ treatment had higher antibody production against Newcastle virus $(P<0.05)$. $\mathrm{C}$ and $E$ treatment equally increased antibody titer against SRBC and Influenza virus $(P<0.05)$.

The 12, 16 and 20\% DAP in broilers diet increased antibody titer production against SRBC $(P<0.05)$; while antibody titer production against Newcastle disease virus non-significantly increased by 12,16 and $20 \%$ DAP in diet $(P>0.05)$.

As observed, broilers fed on control diet had lower antibody titer against SRBC, Newcastle and Influenza diseases virus $(P<0.05)$. Basir and Toghyani $(2017)$ conducted an experiment and used 7.5, 10 and $12 \%$ dried lemon pulp in different rearing phases of broilers. They suggested that antibody titer against Influenza diseases virus significantly decreased $(P<0.05)$. The findings of Abbasi et al. (2015) is in contrast to present study, they reported that supplementing citrus pulp up to $2 \%$ in broilers diet had no effect on humoral immunity of broilers. Nobakht (2013) revealed that heterophil to lymphocyte ratio on broilers fed on $5 \%$ dried lemon pulp insignificantly tended to increase.

Pourhossein et al. (2015) fed on broilers with sweet orange peel extracts, they observed that antibody production against SRBC was tended to be higher than control group $(P>0.05)$. Also, IgG and IgM titers significantly increased $(P<0.05)$. Serum Newcastle disease antibody titer were positively affected by treatments at $28-42$ days of age. In several reports, natural feed additives are known as a strong immune factor (Khan et al. 2012). Haq et al. (1999) reported that broilers given garlic powder showed significantly higher antibody titer against Newcastle diseases virus 


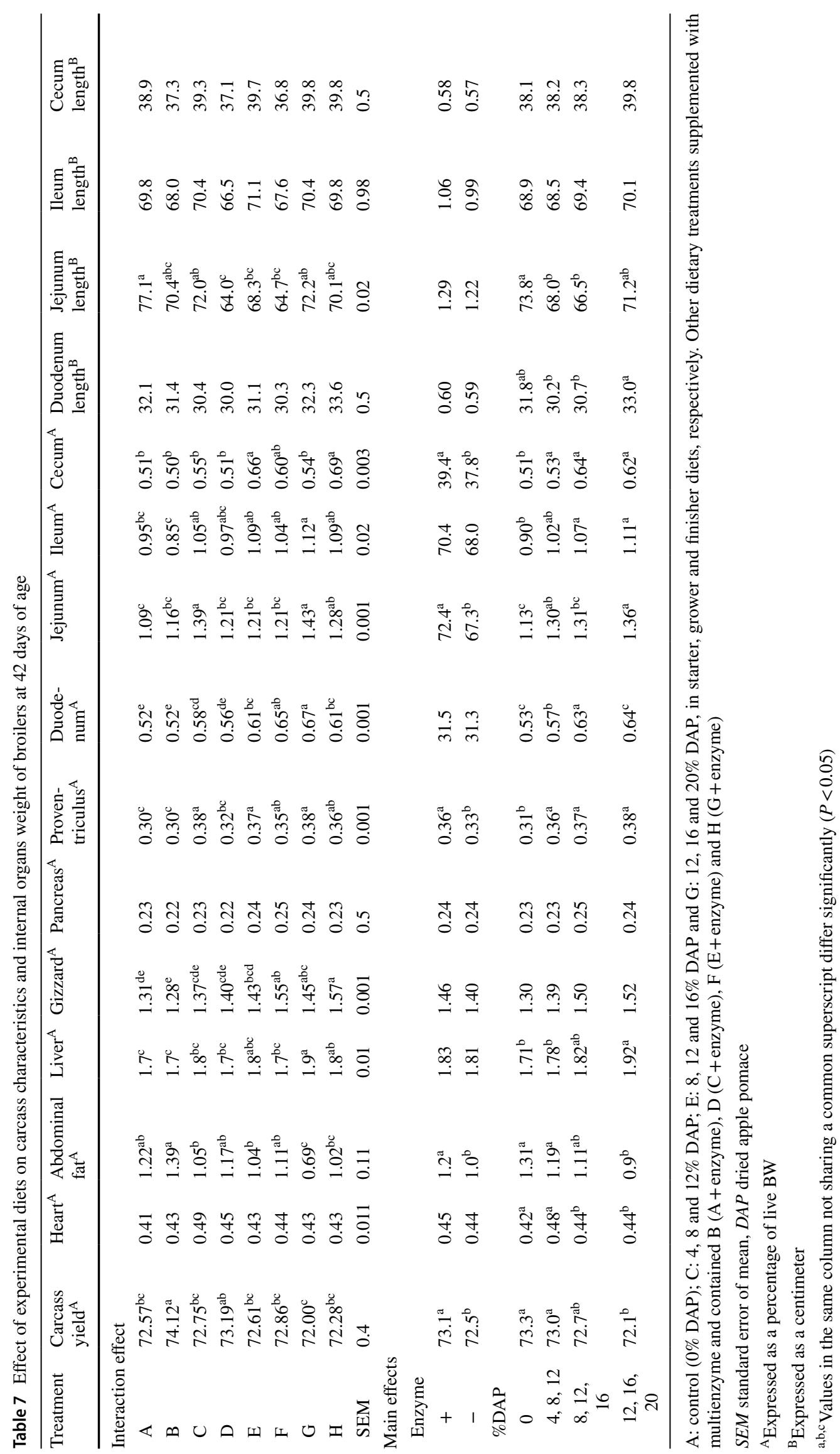


Table 8 Effect of experimental diets on lymphoid organs at 42 days, antibody titers against Newcastle and influenza virus at day 24 of age and antibody titers against SRBC at day 28 of age

\begin{tabular}{|c|c|c|c|c|c|}
\hline Treatment & $\begin{array}{l}\text { New castle } \\
(\log 2)\end{array}$ & Influenza $(\log 2)$ & SRBC $(\log 2)$ & $\begin{array}{l}\text { Bursa of } \\
\text { fabricius }\end{array}$ & Spleen $^{\mathrm{A}}$ \\
\hline \multicolumn{6}{|c|}{ Interaction effect } \\
\hline A & $3.4^{\mathrm{b}}$ & $2.3^{\mathrm{c}}$ & $6.1^{\mathrm{b}}$ & 0.06 & 0.10 \\
\hline B & $3.7^{\mathrm{ab}}$ & $2.5^{\mathrm{bc}}$ & $6.7^{\mathrm{ab}}$ & 0.06 & 0.09 \\
\hline $\mathrm{C}$ & $4.4^{\mathrm{a}}$ & $3^{\mathrm{a}}$ & $7^{\mathrm{a}}$ & 0.05 & 0.10 \\
\hline D & $4.2^{\mathrm{a}}$ & $2.6^{\mathrm{abc}}$ & $6.7^{\mathrm{ab}}$ & 0.07 & 0.09 \\
\hline E & $4^{\mathrm{ab}}$ & $3^{a}$ & $6.8^{\mathrm{ab}}$ & 0.08 & 0.11 \\
\hline $\mathrm{F}$ & $3.8^{\mathrm{ab}}$ & $2.7^{\mathrm{abc}}$ & $7^{\mathrm{a}}$ & 0.07 & 0.11 \\
\hline G & $4.2^{\mathrm{a}}$ & $2.8^{\mathrm{ab}}$ & $7.1^{\mathrm{a}}$ & 0.08 & 0.10 \\
\hline $\mathrm{H}$ & $3.7^{\mathrm{ab}}$ & $2.9^{\mathrm{ab}}$ & $7.1^{\mathrm{a}}$ & 0.08 & 0.10 \\
\hline SEM & 0.24 & 0.09 & 0.29 & 0.008 & 0.5 \\
\hline \multicolumn{6}{|l|}{ Main effects } \\
\hline \multicolumn{6}{|l|}{ Enzyme } \\
\hline+ & 4.0 & 2.8 & 6.8 & 0.07 & 0.10 \\
\hline- & 3.9 & 2.7 & 6.9 & 0.07 & 0.10 \\
\hline \multicolumn{6}{|l|}{$\% \mathrm{DAP}$} \\
\hline 0 & $3.6^{\mathrm{b}}$ & 2.4 & $6.4^{\mathrm{b}}$ & 0.06 & 0.10 \\
\hline $4,8,12$ & $4.3^{\mathrm{a}}$ & 2.8 & $6.9^{\mathrm{ab}}$ & 0.07 & 0.10 \\
\hline $8,12,16$ & $3.9^{\mathrm{ab}}$ & 2.9 & $6.9^{\mathrm{ab}}$ & 0.05 & 0.11 \\
\hline $12,16,20$ & $4.0^{\mathrm{ab}}$ & 2.9 & $7.1^{\mathrm{a}}$ & 0.05 & 0.11 \\
\hline
\end{tabular}

A: control (0\% DAP); C: 4, 8 and 12\% DAP; E: 8, 12 and 16\% DAP and G: 12,16 and 20\% DAP, in starter, grower and finisher diets, respectively. Other dietary treatments supplemented with multienzyme and contained B (A+enzyme), D ( $\mathrm{C}+$ enzyme), F ( $\mathrm{E}+$ enzyme) and $\mathrm{H}(\mathrm{G}+$ enzyme $)$

$S E M$ standard error of mean, DAP dried apple pomace, $S R B C$ sheep red blood cell

${ }^{\mathrm{A}}$ Expressed as a percentage of live BW

${ }^{\text {a,b,c }}$ Values in the same column not sharing a common superscript differ significantly $(P<0.05)$ and Infectious bronchial disease; while, Jafari et al. (2008) reported that garlic powder in broilers diet had no beneficial effects on antibody production, which is in line with our findings. As reported earlier DAP and enzyme supplementation in broiler diets had no significant effect of lymphoid organs of broiler, base on the literatures the investigations of fruit by-products on lymphoid organs are scarce.

\section{Total antioxidant capacity and blood biochemical}

Table 9 summarized the interaction and main effects of DAP and enzyme supplementation on TAC and blood biochemical parameters of broilers at 42 days of age. The TAC of broilers in control group compared with other treatments was significantly lower $(P<0.05)$. The broilers fed on $\mathrm{G}$ treatment gained the highest TAC $(P<0.05)$. The 12,16 and 20\% DAP in broiler diet caused to TAC enhanced $(P<0.05)$.

Incorporation of DAP and interaction between DAP and enzyme supplementation significantly affected blood biochemical of broilers $(P<0.05)$. The interaction results revealed that levels of cholesterol, triglyceride, HDL and VLDL in blood serum of broilers significantly reduced by H treatment $(P<0.05)$.
Regard to the main effects of enzyme supplementation, the levels of triglyceride and VLDL in blood serum of broilers fed on diets containing enzyme supplement than broilers fed on diets free of enzyme, significantly enhanced $(P<0.05)$. The levels of cholesterol, triglyceride, HDL and VLDL in broilers received diets contain 12, 16 and $20 \%$ DAP significantly decreased $(P<0.05)$.

In the study of Heidarisafar et al. (2016), total cholesterol, glucose, albumin and total protein in blood serum of broilers were not affected by apple peel waste and enzyme supplementation. However, apple peel waste resulted in higher HDL and LDL concentration than control group $(P>0.05)$, which is similar to obtained results in recent study. This effect could be due to the high fiber level in apple by-products. Mathlouthi et al. (2002) pointed out that indigestible fiber increases the bile acid secretion, which is end products of cholesterol metabolism (Kiyoshi and Schneeman 1989); therefore, the higher excretion of bile acid in small intestine of broilers could increase HDL and decrease LDL in blood serum.

Apple by-products are known as a rich source of polyphenolic compounds (Soares et al. 2008), and these compounds are able to protect LDL lipids from oxidative stress and enhance their resistance to damage happened by oxidants 
Table 9 Effect of experimental diets on total antioxidant capacity and blood biochemical parameters of broilers at day 42

\begin{tabular}{|c|c|c|c|c|c|c|}
\hline Treatment & $\begin{array}{l}\text { Choles- } \\
\text { terol (mg/ } \\
\text { dL) }\end{array}$ & $\begin{array}{l}\text { Triglycer- } \\
\text { ide (mg/ } \\
\text { dL) }\end{array}$ & $\begin{array}{l}\text { LDL-choles- } \\
\text { terol (mg/dL) }\end{array}$ & $\begin{array}{l}\text { HDL-choles- } \\
\text { terol (mg/dL) }\end{array}$ & VLDL (mg/dL) & $\mathrm{TAC}(\mathrm{mmol} / \mathrm{L})$ \\
\hline \multicolumn{7}{|c|}{ Interaction effect } \\
\hline A & $148^{\mathrm{a}}$ & $111^{\mathrm{a}}$ & $43^{\mathrm{b}}$ & $74^{\mathrm{a}}$ & $21^{\mathrm{a}}$ & $1.12^{\mathrm{c}}$ \\
\hline B & $140.3^{\mathrm{ab}}$ & $95^{\mathrm{abc}}$ & $46^{\mathrm{ab}}$ & $75^{\mathrm{a}}$ & $18^{\mathrm{bc}}$ & $1.16^{\mathrm{c}}$ \\
\hline $\mathrm{C}$ & $133.6^{\mathrm{bc}}$ & $88^{\mathrm{bcd}}$ & $47^{\mathrm{ab}}$ & $74^{\mathrm{a}}$ & $15^{\text {cde }}$ & $1.31^{\mathrm{bc}}$ \\
\hline $\mathrm{D}$ & $131^{\mathrm{bc}}$ & $82^{\text {cde }}$ & $51^{\mathrm{a}}$ & $75^{\mathrm{a}}$ & $15^{\mathrm{ed}}$ & $1.32^{\mathrm{bc}}$ \\
\hline $\mathrm{E}$ & $126^{\mathrm{c}}$ & $101^{\mathrm{ab}}$ & $48^{\mathrm{ab}}$ & $77^{\mathrm{a}}$ & $20^{\mathrm{ab}}$ & $1.3^{\mathrm{bc}}$ \\
\hline $\mathrm{F}$ & $141^{\mathrm{ab}}$ & $88^{\text {bcd }}$ & $50^{\mathrm{ab}}$ & $76^{\mathrm{a}}$ & $16^{\mathrm{cd}}$ & $1.38^{\mathrm{abc}}$ \\
\hline G & $127^{\mathrm{c}}$ & $72^{\mathrm{de}}$ & $53^{\mathrm{a}}$ & $68^{\mathrm{ab}}$ & $15^{\text {cde }}$ & $1.6^{\mathrm{a}}$ \\
\hline $\mathrm{H}$ & $123^{\mathrm{c}}$ & $65^{\mathrm{e}}$ & $50^{\mathrm{ab}}$ & $61^{\mathrm{b}}$ & $13^{\mathrm{e}}$ & $1.42^{\mathrm{ab}}$ \\
\hline SEM & 4.5 & 6.5 & 2.87 & 3.59 & 1.02 & 0.02 \\
\hline \multicolumn{7}{|l|}{ Main effects } \\
\hline \multicolumn{7}{|l|}{ Enzyme } \\
\hline+ & 134 & $93^{\mathrm{a}}$ & 48 & 48 & $18^{\mathrm{a}}$ & 1.3 \\
\hline- & 134 & $83^{\mathrm{b}}$ & 50 & 50 & $16^{\mathrm{b}}$ & 1.3 \\
\hline \multicolumn{7}{|l|}{$\%$ DAP } \\
\hline 0 & $144^{\mathrm{a}}$ & $103^{\mathrm{a}}$ & $45^{\mathrm{b}}$ & $75^{\mathrm{a}}$ & $20^{\mathrm{a}}$ & $1.14^{\mathrm{c}}$ \\
\hline $4,8,12$ & $133^{\mathrm{b}}$ & $85^{\mathrm{a}}$ & $49^{\mathrm{ab}}$ & $75^{\mathrm{a}}$ & $16^{\mathrm{b}}$ & $1.31^{\mathrm{bc}}$ \\
\hline $8,12,16$ & $134^{\mathrm{b}}$ & $95^{\mathrm{ab}}$ & $49^{\mathrm{ab}}$ & $77^{\mathrm{a}}$ & $19^{\mathrm{a}}$ & $1.34^{\mathrm{ab}}$ \\
\hline $12,16,20$ & $125^{\mathrm{b}}$ & $69^{c}$ & $52^{\mathrm{a}}$ & $65^{\mathrm{b}}$ & $15^{\mathrm{b}}$ & $1.51^{\mathrm{a}}$ \\
\hline
\end{tabular}

A: control (0\% DAP); C: 4, 8 and 12\% DAP; E: 8, 12 and 16\% DAP and G: 12,16 and 20\% DAP, in starter, grower and finisher diets, respectively. Other dietary treatments supplemented with multienzyme and contained B (A+enzyme), D ( $\mathrm{C}+$ enzyme $), \mathrm{F}(\mathrm{E}+$ enzyme $)$ and $\mathrm{H}(\mathrm{G}+$ enzyme $)$

$T A C$ total antioxidant capacity, SEM standard error of mean

a,b,c Values in the same column not sharing a common superscript differ significantly $(P<0.05)$
(Noll et al. 2009). The findings of Nobakht (2013) showed that inclusion of different levels of dried lemon pulp just affected LDL concentration in blood serum of broilers $(P<0.05)$. The active substances like pectin in citrus pulps has desirable effect on blood biochemical parameters in human and animals (Baker 1994; Levitt et al. 1980; Poynard et al. 1980; Schwartz et al. 1988).

It was reported that immune modulating effects of natural feed extracts are associated with their ability to increase phagocytosis of potential macrophages, increase production of interleukins, interferon-Y and tumor necrosis factor secretary metabolism of macrophages, antigen presenting cells and antioxidant functions (Khan et al. 2012).

Alzawqari et al. (2016) implied that $0.8 \%$ sweet orange peel significantly increased total antioxidant capacity $(P<0.05)$. Also, Manthey (2004) and Anagnostopoulou et al. (2005) reported that citrus peel includes substances with antioxidant features that are attributable to the flavones.

\section{Small intestine morphology}

According to the morphological study of small intestine of broilers in Table 10, jejuna villous height of broilers influenced by interaction effect of DAP and enzyme supplementation $(P<0.05)$. The interaction of DAP and enzyme supplementation could significantly affected illeal villous height and crypt depth of broilers $(P<0.05)$. Also, addition of enzyme to broiler diet affected crypt depth of ileum $(P<0.05)$. The main effect of DAP in broilers diet showed significant effect on villous height, crypt depth and their ratio in ileum of broilers $(P<0.05)$.

The obtained findings showed that, interaction effect of DAP and enzyme supplementation significantly affected ileum villous height of broilers $(P<0.05)$. The fruits such as apple which is rich in pectin and extra feeding of fiber sources with high molecular weight or those with high methoxyl contents could cause to expansion of the villous intestinal and increases goblet cell numbers which produce mucin and negatively affect nutrient absorption (Langhout et al. 1999).

Basir and Toghyani (2017) fed the broilers with incremental levels of dried lemon pulp, they suggested that ileum morphometric structure of broilers were not affected by experimental diets, and 7.5, 10 and 12\% dried lemon pulp in broilers diet reduced crypt depth of jejunum; while, it was expected that to increased crypt depth. This might be attributed to the presence of tannins and soluble fiber in fruit by-products (Montagne et al. 2003). 
Table 10 Effect of experimental diets on intestinal morphology of broilers at day 42 of age

\begin{tabular}{|c|c|c|c|c|c|c|}
\hline Villus height/crypt ratio & Villus height $(\mu \mathrm{m})$ & $\begin{array}{l}\text { Crypt depth } \\
(\mu \mathrm{m})\end{array}$ & $\begin{array}{l}\text { Villus height/ } \\
\text { crypt ratio }\end{array}$ & Villus height $(\mu \mathrm{m})$ & Crypt depth $(\mu \mathrm{m})$ & $\begin{array}{l}\text { Villus } \\
\text { height/crypt } \\
\text { ratio }\end{array}$ \\
\hline \multicolumn{7}{|l|}{ Interaction effect } \\
\hline A & $1163^{\mathrm{bc}}$ & 224 & 5.85 & $889^{a}$ & $202^{\mathrm{a}}$ & 4.69 \\
\hline $\mathrm{B}$ & $1337^{\mathrm{a}}$ & 216 & 6.11 & $822^{\mathrm{abc}}$ & $181^{\mathrm{ab}}$ & 4.71 \\
\hline $\mathrm{C}$ & $1308^{\mathrm{ab}}$ & 207 & 6.36 & $870^{\mathrm{ab}}$ & $157^{\mathrm{cd}}$ & 5.18 \\
\hline $\mathrm{D}$ & $1071^{\mathrm{c}}$ & 196 & 5.41 & $741^{\mathrm{c}}$ & $148^{\mathrm{d}}$ & 4.95 \\
\hline $\mathrm{E}$ & $1063^{c}$ & 194 & 5.35 & $766^{\mathrm{bc}}$ & $172^{\mathrm{cb}}$ & 4.48 \\
\hline $\mathrm{F}$ & $1263^{\mathrm{ab}}$ & 221 & 6.02 & $818^{a b c}$ & $155^{\mathrm{cd}}$ & 5.01 \\
\hline G & $1025^{\mathrm{abc}}$ & 186 & 5.8 & $924^{\mathrm{a}}$ & $198^{\mathrm{a}}$ & 4.5 \\
\hline $\mathrm{H}$ & $1285^{\mathrm{ab}}$ & 210 & 5.91 & $838^{\mathrm{abc}}$ & $173^{\mathrm{cb}}$ & 4.64 \\
\hline SEM & 225.9 & 16.2 & 0.01 & 106.6 & 4.5 & 0.002 \\
\hline \multicolumn{7}{|l|}{ Enzyme/DAP } \\
\hline \multicolumn{7}{|l|}{ Enzyme } \\
\hline+ & 1239 & 211 & 5.9 & $805^{\mathrm{b}}$ & $165^{\mathrm{b}}$ & 4.7 \\
\hline- & 1185 & 203 & 5.8 & $863^{\mathrm{b}}$ & $183^{\mathrm{a}}$ & 4.8 \\
\hline \multicolumn{7}{|l|}{$\%$ DAP } \\
\hline 0 & 1250 & 220 & 6 & $855.7^{\mathrm{ab}}$ & $192^{\mathrm{a}}$ & $4.7^{\mathrm{ab}}$ \\
\hline $4,8,12$ & 1190 & 202 & 5.9 & $806.1^{\mathrm{ab}}$ & $153^{\mathrm{b}}$ & $5.1^{\mathrm{a}}$ \\
\hline $8,12,16$ & 1163 & 208 & 5.7 & $792.4^{\mathrm{b}}$ & $164^{\mathrm{b}}$ & $4.8^{\mathrm{ab}}$ \\
\hline $12,16,20$ & 1246 & 198 & 5.9 & $881.3^{\mathrm{a}}$ & $186^{\mathrm{a}}$ & $4.6^{\mathrm{b}}$ \\
\hline
\end{tabular}

A: control (0\% DAP); C: 4, 8 and 12\% DAP; E: 8, 12 and 16\% DAP and G: 12, 16 and 20\% DAP, in starter, grower and finisher diets, respectively. Other dietary treatments supplemented with multienzyme and contained B $(\mathrm{A}+$ enzyme), D $(\mathrm{C}+\mathrm{enzyme}), \mathrm{F}(\mathrm{E}+\mathrm{enzyme})$ and $\mathrm{H}$ ( $\mathrm{G}+$ enzyme)

SEM standard error of mean

a,b,c Values in the same column not sharing a common superscript differ significantly $(P<0.05)$

\section{Conclusion}

In conclusion, enzyme supplementation had positive effect on DFI, DWG and BW at different rearing phases $(P<0.05)$. Administration of 12, 16 and 20\% DAP deteriorated growth performance of broilers. Carcass characteristics and internal organs of broilers at 42 days of age did not show specific trend between treatments. Between diets, inclusion of 4,8 and $12 \%$ DAP significantly increased antibody titer production against NDV, IDV and SRBC; while, TAC significantly increased by 12,16 and 20 DAP $(P<0.05)$. Enzyme administration had no effect on TAC and antibody titer production. Blood biochemical parameters of broilers at 42 days of age significantly decreased by 12,16 and $20 \%$ DAP plus enzyme $(P<0.05)$. Inclusion of 4,8 and $12 \%$ DAP in broilers diet significantly decreased the jejunum villous height, and crypt depth of broilers fed on 12, 16 and 20\% DAP non-significantly decreased $(P>0.05)$. The inclusion of 4,8 and $12 \%$ DAP plus enzyme significantly decreased villous height and crypt depth in jejunum $(P<0.05)$, although the mentioned parameters increased by 12,16 and $20 \%$ DAP plus enzyme $(P>0.05)$. Therefore, dietary consumption of DAP at 12,16 and $20 \%$ in broilers diet is not recommended.
Open Access This article is distributed under the terms of the Creative Commons Attribution 4.0 International License (http://creativeco mmons.org/licenses/by/4.0/), which permits unrestricted use, distribution, and reproduction in any medium, provided you give appropriate credit to the original author(s) and the source, provide a link to the Creative Commons license, and indicate if changes were made.

\section{References}

Abbasi H, Seidavi A, Liu W, Asadpour L (2015) Investigation on the effect of different levels of dried sweet orange (Citrus sinensis) pulp on performance, carcass characteristics and physiological and biochemical parameters in broiler chicken. Saudi J Biol Sci 22:139-146. https://doi.org/10.1016/j.sjbs.2014.09.006

Ahmad GA (2004) Simultaneous use of apple pomace and molasses as a source of energy for broiler. Indian J Poult Sci 39(2):179-181

Akhlaghi A, Ahangari YJ, Navidshad B, Pirsaraei ZA, Zhandi M, Deldar H, Rezvani MR, Dadpasand M, Hashemi SR, Poureslami R, Peebles ED (2014) Improvements in semen quality sperm fatty acids and reproductive performance in aged Cobb 500 breeder roosters fed diets containing dried ginger rhizomes (Zingiber officinale). Poult Sci 93:1236-1244. https://doi.org/10.3382/ ps.2013-03617

Alzawqari MH, Al-Baddany AA, Al-Baadani HH, Alhidary IA, Ullah Khan R, Aqil GM, Abdurab A (2016) Effect of feeding dried sweet orange (Citrus sinensis) peel and lemon grass (Cymbopogon 
citratus) leaves on growth performance, carcass traits, serum metabolites and antioxidant status in broiler during the finisher. Environ Sci Poult Res Int 23(17):17077-17083. https://doi. org/10.1007/s11356-016-6879-7

Anagnostopoulou MA, Kefalas P, Kokkalou E, Assimopoulou AN, Papageorgiou VP (2005) Analysis of antioxidant compounds in sweet orange peel by HPLC-diode array detection-electrospray ionization mass spectrometry. Biomed Chromatgr 19:138-148. https://doi.org/10.1002/bmc.430

AOAC (1994) Association of Official Analytical Chemists, Official Methods of Analysis-Animal Feed Section

Ayhan V, Duru AA, Ozkaya S (2009) Possibilities of using dried apple pomace in broiler chicken diets. Kafkas Univ Veteriner Fakultesi Dergisi 15(5):669-672

Baker RA (1994) Potential dietary benefits of citrus pectin and fiber. Food Technol 48:133-139

Basir R, Toghyani M (2017) Effect of dietary graded levels of dried lemon (Citrus aurantifulia) pulp on performance, intestinal morphology, and humoral immunity in broiler chickens. Int $\mathrm{J}$ Recycl Org Waste Agric 6(2):125-132

Bedford MR, Patridge GG (2011) Enzymes in farm animal nutrition. CABI Publication, Wallingford

Benize IFF, Strain J (1996) The ferric reducing ability of plasma (FRAP) as a measure of "antioxidant" power: the FRAP assay. Anal Biochem 239:70-76. https://doi.org/10.1006/ abio.1996.0292

Campbell GL, Rossnager BF, Classen HL, Thacker PA (1986) Genotypic and environmental differences in extract viscosity of barley and their relationship to its nutritive value for broiler chickens. Anim Feed Sci Technol 26:221-230. https://doi. org/10.1016/0377-8401(89)90036-9

Carrijo AS, Madeira LA, Sartori JR, Pezzato AC, Goncalves JC, Cruz V, Kuibida KV, Pinheiro DF (2005) Powdered garlic in the alternative feeding of broiler chickens. Pesquisa Agropecuaria Brasileira 40(7):673-679

Cetkovic G, Canadanovic-Brunet J, Djilas S, Savatovic S, Mandic A, Tumbas V (2007) Assessment of polyphenolic content and antiradical characteristics of apple pomace. Food Chem 109:340-347. https://doi.org/10.1016/j.foodchem.2007.12.046

Chaudry MA, Badshan A, Bibi N, Zeb A, Ahmed T, Ali S, Termeulen U (2004) Citrus waste in poultry rations. Arch Geflugelk 68:206-210

Choct M, Hughes RJ, Wang J, Bedford MR, Morgan AJ, Annison G (1996) Increased small intestine fermentation is partly responsible for the anti-nutritive activity on non starch polysaccharides in chickens. Br Poult Sci 37:609-621. https://doi.org/10.1080/00071 669608417891

Correia R, Magalhaes M, Macedo G (2007) Protein enrichment of pineapple waste with Saccharomyces cerevisiae by solid state bioprocessing. J Sci Ind Res 66:259-262

Fanimo AO, Oduguwa OO, Alade AA, Ogunnaike TO, Adesehinwa AK (2003) Growth performance nutrient digestibility and carcass characteristic of growing rabbits fed cashew apple waste. Livest Res Rural Dev 15(8):15-23

Ganai AM, Mattoo FA, Singh PK, Ahmad HA, Samoon MH (2006) Chemical composition of some feeds, fodders and plane of nutrition of livestock of Kashmir valley. SKUAST J R 8:145-151

García Dineiro Y, Valles Suarez B, Picinelli Lobo A (2009) Phenolic and antioxidant composition of by-products from the cider industry: apple pomace. Food Chem 117(4):731-738. https://doi. org/10.1016/j.foodchem.2009.04.049

Gullion B, Yanez R, Alonso JL, Parajo JC (2008) L-Lactic acid production from apple pomace by sequential hydrolysis and fermentation. Bioresour Technol 99:308-319. https://doi.org/10.1016/j. biortech.2006.12.018
Haq AU, Mera KA, Rasool S (1999) Effect of supplementing Allium sativum (Garlic) and Azadirachta indica (Neem) leaves in broiler feeds on their blood cholesterol, triglycerides and antibody titre. Int J Agric Biol 1:125-127

Heidarisafar Z, Sadeghi GhA, Karimi A, Azizi O (2016) Apple peel waste as a natural antioxidant for heat-stressed broiler chickens. Trop Anim Health Prod 48(4):831-835. https://doi.org/10.1007/ s11250-016-1001-1

Hesselman K, Aman P (1986) The effect of $\beta$-glucanase on the utilisation of starch and nitrogen by broiler chickens fed on barley of low and high viscosity. Anim Feed Sci Technol 15:83-93. https://doi. org/10.1016/0377-8401(86)90015-5

Jafari RA, Jalali MR, Ghorbanpoor M, Saraei SM (2008) Effect of dietary garlic on immune response of broiler chicks to live Newcastle Disease vaccine. Pak J Biol Sci 11:1848-1851. https://doi. org/10.3923/pjbs.2008.1848.1851

Kang L, Hao H, Zhenying Y, Li X, Kang G (2009) The advances in the research of apple ring rot. Chin Agric Sci Bull 25:188-191

Khan RU, Naz S, Nikousefat Z, Tufarelli V, Laudadio V (2012) Thymus vulgaris: alternative to antibiotics in poultry feed. World Poult Sci J 68:401-408. https://doi.org/10.1017/S0043933912000517

Khayat Nouri M, Kargari Rezapour A (2011) Effect of apple supplementation on serum lipids and lipoproteins level in cholesterol fed male rat. Middle East J Sci Res 9(6):744-748

Kilinc OO, Ayhan V (2002) Using possibility of dried tomato and apple pomaces in quail diets. J Anim Sci 43(2):35-43

Kiyoshi E, Schneeman BO (1989) Interaction of bile acids, phospholipids, cholesterol and triglyceride with dietary fibers in the small intestine of rats. J Nutr 119:1100-1106. https://doi.org/10.1093/ jn/119.8.1100

Langhout DJ, Schutte JB, Van Leeuwen P, Wiebenga J, Tamminga S (1999) Effect of dietary high-and low-methylated citrus pectin on the activity of the ileal microflora and morphology of the small intestinal wall of broiler chicks. Br Poult Sci 40:340-347. https:// doi.org/10.1080/00071669987421

Levitt NS, Vinik AI, Sive AA, Child PT, Jackson WP (1980) The effect of dietary fiber on glucose and hormone responses to a mixed meal in normal subjects and in diabetic subjects with and without autonomic neuropathy. Diabetes Care 3:515-519. https://doi. org/10.2337/diacare.3.4.515

Manthey JA (2004) Fractionation of orange peel phenols in ultrafiltered molasses and mass balance studies of their antioxidant levels. J Agric Food Chem 52:7586-7592. https://doi.org/10.1021/jf049 $083 \mathrm{j}$

Mathlouthi N, Lalles JP, Lepersq P, Juste C, Larbier M (2002) Xylanase and $\beta$-glucanase supplementation improve conjugated bile acid fraction in intestinal contents and increase villous size of small intestine wall in broiler chickens fed ray-based diet. J Anim Sci 80:2773-2779. https://doi.org/10.2527/2002.80112773x

Matoo FA, Bhat GA, Banday MT, Ganai TAS (2001) Performance of broiler fed on apple pomace diets supplemented with enzymes. Indian J Anim Nutr 18:349-352

Montagne L, Pluske JR, Hampson DJ (2003) A review of interactions between dietary fibre and the intestinal mucosa, and their consequences on digestive health in young non-ruminant animals. Anim Feed Sci Technol 108:95-117. https://doi.org/10.1016/ S0377-8401(03)00163-9

Nobakht A (2013) Effects of different levels of dried lemon (Citrus aurantifulia) pulp on performance, carcass traits, blood biochemical and immunity parameters of broilers. Iran J Appl Anim Sci 3:145-151

Noll C, Hamelet J, Matulewicz E, Paul JL, Delabar JM, Janel N (2009) Effects of red wine polyphenolic compounds on paraoxonase-1 and lectin-like oxidized low-density lipoprotein receptor-1 in hyperhomocysteinemic mice. J Nutr Biochem 20:586-596. https ://doi.org/10.1016/j.jnutbio.2008.06.002 
Pettersson D, Aman P (1986) Enzyme supplementation of a poultry diet containing rye and wheat. Br Poult Sci 62:139-149. https:// doi.org/10.1079/bjn19890014

Pourhossein Z, Qotbi AAA, Seidavi A, Laudadio V, Centoducati G, Tufarelli V (2015) Effect of different levels of dietary sweet orange (Citrus sinensis) peel extract on humoral immune system responses in broiler chickens. Anim Sci J 86:105-110. https://doi. org/10.1111/asj.12250

Poynard T, Slama G, Delage A, Tchobroutsky G (1980) Pectin efficacy in insulin-treated diabetics assessed by the artificial pancreas. Lancet 1:158-165. https://doi.org/10.1016/s0140-6736(80)90644 $-3$

Rizal Y, Endo Mahata M, Andriani M, Wu G (2010) Utilization of juice wastes as corn replacement in the broiler diet. Int J Poult Sci 9:886-889

SAS Institute (1997) SAS (statistical analysis system), 1997. User guide statistics. SAS Institute Inc, Cary

Schwartz SE, Levine RA, Weinstock RS, Petokas S, Mills CA, Thomas FD (1988) Sustained pectin ingestion: effect on gastric emptying and glucose tolerance in non-insulin dependent diabetic patients. Am J Clin Nutr 48:1413-1417. https://doi.org/10.1093/ ajcn/48.6.1413

Sehm J, Treutter D, Lindermayer H, Meyer HH, Pfaffi MW (2011) The influence of apple or red grape pomace enriched piglet diet on blood parameters bacterial colonization and marker gene expression in piglet white blood cells. Food Nutr Sci 2:366-376. https ://doi.org/10.4236/fns.2011.24052
Soares MC, Riberio ET, Kuskoski EM, Gonzaga LV, Lima A, Filho MJM, Fett R (2008) Composition of phenolic acids content in apple (Malus sp) pomace. J Agric Sci 29:339-348. https://doi. org/10.5433/1679-0359.2008v29n2p339

Sudha ML, Baskaram V, Leelavathi K (2007) Apple pomace as a source of dietary fiber and polyphenols and its effect on the rheological characteristics and cake making. Food Chem 104:686-692. https://doi.org/10.1016/j.foodchem.2006.12.016

Toghyani M, Emadinia A (2016) Encyclopedia of poultry feed staffs Esfahan, Iran. (In Persian)

Wegmann TG, Smithies OA (1966) Simple hemagglutination system requiring small amounts of red blood cells and antibodies. Transfusion 6:67-73. https://doi.org/10.1111/j.1537-2995.1966.tb046 96.x

Yildiz G, Dikicioglu T, Sacakli P (1998) The effect of dried apple pomace and grindazym added to the layer rations on egg production and egg quality. J Turk Vet 10(3):34-39

Zafar F, Idrees M, Ahmad Z (2005) Use of apple by products in poultry rations of broiler chicks in Karachi. Pak J Physiol 1(2):32-34

Publisher's Note Springer Nature remains neutral with regard to jurisdictional claims in published maps and institutional affiliations. 